\title{
REVIEW OF THE CURRENT STATUS OF STUDY OXYTROPIS
}

\author{
AMIRKHANOVA A Sh*, USTENOVA G 0 \\ Department of Pharmacy, Asfendiyarov, Kazakh National Medical University, Almaty, Republic of Kazakhstan. \\ Email: Akerke_1706@mail.ru
}

Received: 14 November 2017, Revised and Accepted: 15 January 2018

\begin{abstract}
The use of plants for medical purposes has been known since ancient times, and despite progress in the synthesis of medicinal products, herbal remedies continue to occupy a significant place in modern medicine. As promising sources of biologically active substances of natural origin, attention is attracted by representatives of the domestic flora from the family Fabaceae. The article gives an analysis of the current state of the study of the genus of Oxytropis and shows the prospects for their comprehensive study. Work in the herbarium fund of the Institute with a collection of species of Oxytropis glabra Lam. DC. allowed to identify the presence of at least 10 herbarium sheets. While analyzing the internet sources, we collected materials on the genus and species of Oxytropis which have been investigated for many years. When analyzing internet resources, it was established that the widely used traditional Tibetan, Chinese, Mongolian, and Buryat medicine should include representatives of the genus Oxytropis (DC.) of the family Fabaceae (L.).We have studied the species of the Oxytropis and compiled a table on their chemical composition and pharmacological action.
\end{abstract}

Keywords: Oxytropis, Oxytropis glabra Lam. DC., Leguminosae, Papillionoideae, Locoweed, Official, Traditional medicine, Chinese, Tibetan, Flora of Kazakhstan

(c) 2018 The Authors. Published by Innovare Academic Sciences Pvt Ltd. This is an open access article under the CC BY license (http://creativecommons. org/licenses/by/4. 0/) DOI: http://dx.doi.org/10.22159/ajpcr.2018.v11i4.23656

\section{INTRODUCTION}

Plants used for traditional medicine contain a wide range of substances that can be used to treat chronic as well as infectious diseases [1]. Oxytropis is an important genus of the family Fabaceae (L.) and the subfamily Papillionoideae, also known as "Locoweed." More than 350 species of locoweeds are common in the temperate and arctic regions of the Northern Hemisphere, where the main centers of species diversity are concentrated in Central and Central Asia, in Southern Siberia, in the Altai and the Far East of Northeast Asia. Locoweeds grow mainly in mountain meadows and steppes, stony slopes, in the arctic and alpine tundra. They occur on the stony slopes of the Tien Shan and the Central Sayan Mountains, in the mountain steppes of Northeast Yakutia [2].

Oxytropis genus includes both arcto-alpine species confined to stony habitats, rocks and tundra of the Arctic region and the Alpine belt of mountains, and steppe forms connected with steppe groupings. Some of them (Oxytropis chankaensis Jurtz, Oxytropis gmelinii Fisch. ex Boriss., and Oxytropis baschkirensis Knjasev) were investigated on the territory of Russia [3]. Turkish botanists Seher Karaman Erkul and Zeki Aytac conducted an audit of species of the genus Oxytropis growing in Turkey [4,5]. In Kamchatka, Cholinas et al. investigated the genetic variations of six species of local locoweeds [6]. In one of his works, Malyshev presented a system analysis of the genus Oxytropis in Asian Russia [7]. According to his data, 142 species and 24 subspecies in 5 subgenera and 16 sections were found in Siberia and the Russian Far East, of which, as the author notes, 15 taxa are unjustifiably identified as independent species. The work also presents data on the number of chromosomes, plant patterns, and the area maps. Yu and Zibzeev analyzed the ontogenetic and vital structure of seven populations of the endemic species of alpine meadows of Altai Oxytropis sulphured (Fisch. Ex DC.) Ledeb. in various cenotic conditions of the highlands of the Rudny Altai (the Ivanovsky and Prohodnoy ranges) and the Saur [8].

A great work devoted to the Tien Shan locoweeds, their composition, botanical-geographical relations, morphological characteristics, and economic significance was done by Abdulina. According to her data,
119 species from 15 sections of the Oxytropis genus were recorded in Kazakhstan, of which 36 species $32.5 \%$ are endemic and 10 are listed in the Red Book.

Many types of Oxytropis are of practical importance as feed, melliferous, medicinal, and ornamental plants. Hence, Oxytropis deflexa and Oxytropis glabra are fodder on natural pastures. Cultivation of these species is promising. Other species of the genus are melliferous, such as Oxytropis lapponica and Oxytropis pilosa, and some species can be used as decorative (for example, Oxytropis pilosa). Oxytropis tragacantoides, which has the life form of a shrub, traditionally is used as fuel in the republics of Tyva and Altai of the Russian Federation and in Mongolia [9].

Herbal medicine has been commonly used over the years for treatment and prevention of diseases and health promotion and quality of life. However, there is a lack of a systematic approach to assess their safety and effectiveness. The holistic approach to health care makes herbal medicine very attractive to many people in worldwide.

Table 1: The economically significant characteristics of the oxytropis

\begin{tabular}{llll}
\hline View & Decorative & Fodder & Medicinal \\
\hline O. campanulata Vass. & + & - & Tradition \\
O. deflexa (Pallas) DC. & + & + & Tradition \\
O. filiformis DC. & + & + & Tradition \\
O. glabra (Lam.) DC. & + & + & Tradition \\
O. lapponica (Wahkend.) J. Gay & + & + & - \\
O. muricata (Pallas) DC. & + & + & Tradition \\
O. pilosa (L.) DC. & + & Toxic & Tradition \\
O. setosa (Pallas) DC. & + & + & Tradition \\
O. strobilacea Bunge & + & + & - \\
\hline O. campanulata: Oxytropiscampandation
\end{tabular}

O. campanulata: Oxytropis campanulata, O. deflexa: Oxytropis

deflexa, O. filiformis: Oxytropis filiformis, O. glabra: Oxytropis glabra,

O. lapponica: Oxytropis lapponica, O. muricata: Oxytropis muricata,

O. pilosa: Oxytropis pilosa, O. setosa: Oxytropis setosa, O. strobilacea: Oxytropis strobilacea 
The medicinal value of these plants lies in bioactive phytochemical constituents that produce definite physiological action on the human body. Some of the most important bioactive phytochemical constituents are alkaloids, essential oils, flavonoids, tannins, terpenoids, saponins, phenolic compounds, etc. Several herbal secondary metabolites such as flavonoids have been found to protect cells from oxidative damage [10].

Medicinal plants containing flavonoids, as the basis of its composition, are widely used species of the Oxytropis in Tibetan and folk medicine:
Oxytropis falcate, Oxytropis myriophylla, Oxytropis ochrocephala, and $O$. pilosa (L.) DC.

The total flavonoid glycoside was isolated from 0 . falcata, could enhance the secretion of adrenal cortex hormones, and induce a large number of these hormones being released into the peripheral blood stream. In simple terms, the total flavonoid glycoside of $O$. falcate could activate the hypothalamus-pituitary - adrenal axis; improve the body stress to achieve expectorant, anti-inflammatory effect.

Table 2: Chemical components of the species of the Oxytropis

\begin{tabular}{|c|c|c|}
\hline Species & Extracts and methods & Chemical compounds \\
\hline O. falcate Bunge. & $\begin{array}{l}\text { The chloroform extract of } 0 \text {. falcata } \\
\text { was analyzed by HPLC-MS. HPLC } \\
\text { was performed on a } 4.6 * 250 \mathrm{~mm} \\
\text { Diamonsil C18 column packed with } \\
5 \mathrm{um} \text { particles (Dikma, Beijing, } \\
\text { China) at a flow of } 1 \mathrm{~mL} / \mathrm{min} \text {, of } \\
\text { which } 250 \mathrm{uL} / \mathrm{min} \text { was shunting } \\
\text { for the mass spectrometer. The } \\
\text { gradient was from } 5 \% \text { mobile } \\
\text { phase: B containing CAN and } 0.1 \% \\
\text { formic acid (both HPLC-grade, } \\
\text { Sigma-Aldrich) to } 35 \% \text { Bin } 25 \mathrm{~min} \text {, } \\
\text { followed by a washman free } \\
\text { equilibration step the ethyl acetate } \\
\text { extract of } 0 \text {. falcate }\end{array}$ & $\begin{array}{l}\text { N-benzoyl-phenylethylamine, 7-hydroxy-flavonone, 2',4'-Dihydroxy chalcone, } \\
\text { N-benzoyl-Hydroxyl phenylethylamine, 2',4'-Dihydroxy } \\
\text { dihydrochalcone, anagyrine, lupanine, N-cinnamoyl-2-phenylethylamine, } \\
\text { 7-methoxyflavonone, 2'-methoxy- } \\
\text { 4'-hydroxychalcone, 2'-hydroxy-4'methoxychalcone, } \\
\text { 2',4',4-trihydroxychalcone, Pinocembrin, glycyrrhizin, formononetin, pinostrobin } \\
\text { 5-hydroxyl-7-methoxyflavanone, } \\
\text { 4-baptigenin, Oxytropine C, } \\
\text { rhamnetin, m-Methoxyaniline, } \\
\text { 2-monolinolein, } \\
\text { Kaempferol (3-0-(6'- acetyl )- } \beta \text {-D-glucoside, } \beta \text {-daucosterol, anagyrine. } \\
\text { phenethylamine, 7-hydroxyflavone, } \\
\text { 7-hydroxy-flavanon naringenine, } \\
\text { naringetol, apigenin, 2',4'-dihydroxychalcone, phenyl ethyl, chrysin, isoliquiritigenin, } \\
\text { salicin, naringenin, luteolin, quercetin, 2,4-dihydroxy-4'-dimethoxychalcone, } \\
\text { kaempferol, 5,7-dihydroxy-4'-methoxy-hydroxy-2 phenyl, } \\
\text { 3,7-Dihydroxy-2',4'-dimethoxyisoflavan, isorhamnetin, } \\
\beta \text {-sitosterol, myricetin, kaempferide-7-0- } \beta \text {-D-glucopyranoside, } \\
\beta \text {-daucosterin, 5,7-dihydroxy-4'-methoxy-2-phenyl-4-benzopyr, } \\
\text { methoxy-2-phenyl-4-benzopyrone-3-0- } \beta \text {-galactopyranoside, 7-oxositosterol, } \\
\text { 7 } \alpha \text {-hydroxysitosterol, 5,6-dihydroxy-2,7,3',42 tetramethoxy flavone [15,16] }\end{array}$ \\
\hline O. ochrocephala & $\begin{array}{l}\text { The ethanol extract of } 0 \text {. ochrocephala } \\
\text { was analyzed by HPLCMS (Thermo } \\
\text { Fisher, San Jose, CA LCQ). HPLC } \\
\text { was performed on } 4.6^{*} 250 \mathrm{~mm} \\
\text { Diamondsil C18 column packed } \\
\text { with } 5 \text { um particles (Dikma, Beijing, } \\
\text { China) at a flow of } 1 \mathrm{~mL} / \mathrm{min} \text {, of } \\
\text { which } 250 \mathrm{uL} / \mathrm{min} \text { was shunting for } \\
\text { mass spectrometer. The gradient was } \\
\text { from } 5 \% \text { mobile phase B containing } \\
\text { ACN and } 0.1 \% \text { formic acid (both } \\
\text { HPLC-grade, Sigma-Aldrich) to } 35 \% \\
\text { B in } 25 \text { min, followed by a wash and } \\
\text { equilibrations step }\end{array}$ & $\begin{array}{l}\text { 7-methoxy flavonone, 2',4,4'-trihydroxychalcone, pinocembrin, } \\
\text { 2'-hydroxy-4'-dimethoxy chalcone, fermononetin, glycyrrhizin, } \\
\text { 2'-methoxy-4'-hydroxychalcone, N-benzoyl-phenyl ethylamine, } \\
\text { N-cinnamoyl-2-phenylethylamine, 7-methoxyflavanone, } \\
\text { 5-hydroxy-7-methoxyflavanone, 2-monolinoleoyin, Chrysin, } \\
\text { Genistein, Apigenin, luteolin, 3,7-Dihydroxy-2',4' dimethoxyisoflavan, } \\
\text { 7-Hydroxyflavone, isoliquiritigenin, isorhamnetin, quercetin, } \\
\text { myricetin, kaempferol, phenyl ethyl, phenethylamine, genistein, salicin, } \\
\text { 7 } \alpha \text {-hydroxysitosterol, 5,7-dihydroxy-4'-methoxy-hydroxy-2-phenyl, and } \\
\text { 5,7-Dihydroxy-4'-methoxy-2-phenyl-4-benzopyrone-3-0- } \beta \text {-galactopyranoside [17] }\end{array}$ \\
\hline O. myriophylla & $\begin{array}{l}\text { The powders of } 0 \text {. myriophylla were } \\
\text { extracted with } 95 \% \text { EtOH. The extract } \\
\text { was suspended in water and extracted } \\
\text { successively with EtOAc, n-BuOH. The } \\
n \text {-BuOH soluble part was separated } \\
\text { on D101 macroporous resin, silica } \\
\text { gel, Rp-18 silica gel, Sephadex } \\
\text { LH-20 column chromatography, and } \\
\text { HPLC to obtain compounds. The } \\
\text { phytochemical study of } 70 \% \text { ethanol } \\
\text { extract obtained from the whole plant } \\
\text { of } 0 . m y r i o p h y l l a \text { afforded compounds. } \\
\text { The structural elucidations of all } \\
\text { the compounds were based on } \\
\text { extensive spectroscopic methods, } \\
\text { including HRESIMS and 2D-NMR } \\
\text { experiments (HSQC, HMBC, } 1 \mathrm{H}-1 \mathrm{H} \\
\text { COSY, and HSQC-TOCSY), UV }\end{array}$ & 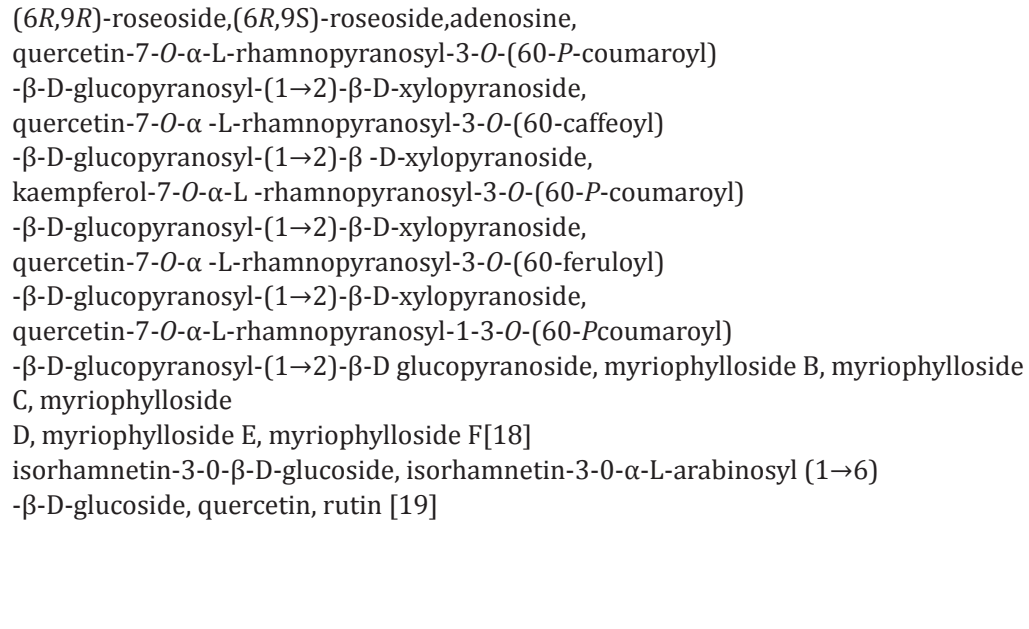 \\
\hline
\end{tabular}

O. falcate: Oxytropis falcate, O. myriophylla: Oxytropis myriophylla, O. ochrocephala: Oxytropis ochrocephala 
Table 3: Some medicinal plant raw materials of the genus Oxytropis (DC.) of the Fabaceae (L.) family

\begin{tabular}{|c|c|c|c|c|}
\hline Species & Guideline in red books & Used in & Chemical composition & Pharmacological properties \\
\hline 1 & 2 & 3 & 4 & 5 \\
\hline O. falcate Bunge. & $\begin{array}{l}\text { The Republic of Tajikistan, } \\
2011\end{array}$ & $\begin{array}{l}\text { Traditional Chinese } \\
\text { medicine }\end{array}$ & $\begin{array}{l}\text { Saponins, alkaloids, } \\
\text { flavonoids, coumarins }\end{array}$ & $\begin{array}{l}\text { Treat inflammation, flu, pain, stop } \\
\text { bleeding, and anthracosis [22] }\end{array}$ \\
\hline O. pilosa (L.) DC. & $\begin{array}{l}\text { The Republic of Belarus, } \\
\text { 2014, the Republic of Mari } \\
\text { El 2013, the Republic of } \\
\text { Sakha (Yakutia) 2000, the } \\
\text { Republic of Estonia } 2008\end{array}$ & Folk medicine & $\begin{array}{l}\text { Phenolcarbonic acids, } \\
\text { alkaloids, coumarins, and } \\
\text { the following flavonoids: } \\
\text { Quercetin, mono- and } \\
\text { diglyco-sides of quercetin, } \\
\text { and kaempferol, as well as } \\
\text { astragalin }\end{array}$ & $\begin{array}{l}\text { Applied for neuroses, } \\
\text { neurasthenia, fever, } \\
\text { vegetovascular dystonia, with } \\
\text { some gynecological diseases } \\
\text { and inflammation of the } \\
\text { appendages [23] }\end{array}$ \\
\hline $\begin{array}{l}\text { O. myriophylla (Pall.) } \\
\text { DC. }\end{array}$ & - & $\begin{array}{l}\text { Traditional Chinese } \\
\text { and folk medicine }\end{array}$ & $\begin{array}{l}\text { Coumarins, alkaloids, } \\
\text { flavonoids (ramnezine, } \\
\text { ramnetin, and their } \\
\text { glycosides), essential oil }\end{array}$ & $\begin{array}{l}\text { Cardiovascular diseases, } \\
\text { blood-resurfacing, diuretic, } \\
\text { antipyretic, anti-inflammatory, } \\
\text { pain-relieving [24] }\end{array}$ \\
\hline $\begin{array}{l}\text { O. muricata (Pall.) } \\
\text { DC. }\end{array}$ & $\begin{array}{l}\text { The Republic of Tuva in } 2009 \text {, } \\
\text { the Krasnoyarsk region, } 2012\end{array}$ & $\begin{array}{l}\text { The Mongolian } \\
\text { medicine }\end{array}$ & $\begin{array}{l}\text { Resins, alkaloid, chemical } \\
\text { composition is not studied } \\
\text { enough }\end{array}$ & $\begin{array}{l}\text { Has strong sedative, narcotic, } \\
\text { tonic, anti-inflammatory, } \\
\text { wound-healing and antimicrobial } \\
\text { action. Encyclopedia of medicinal } \\
\text { plants [25] }\end{array}$ \\
\hline O. lanata (Pall.) DC. & $\begin{array}{l}\text { Transbaikalian Region } \\
\text { 2014, the Republic of } \\
\text { Sakha (Yakutia) } 2000\end{array}$ & Tibetan medicine & $\begin{array}{l}\text { Saponins, triterpene } \\
\text { soyasapogenin, alkaloids, } \\
\text { phenolcarboxylic acids, } \\
\text { astragaline, myricetin, } \\
\text { rhamnetin, rhamnazin }\end{array}$ & $\begin{array}{l}\text { Hemostatic, antipyretic, and } \\
\text { diuretic agents [25] }\end{array}$ \\
\hline O. oxiphylla (Pall) DC. & - & $\begin{array}{l}\text { Chinese and Tibetan } \\
\text { medicine }\end{array}$ & $\begin{array}{l}\text { Coumarins, essential oils, } \\
\text { alkaloids, and the following } \\
\text { flavonoids: rhamnetin, } \\
\text { rhamnazin, and their } \\
\text { glycosides. }\end{array}$ & $\begin{array}{l}\text { Cardiovascular diseases, ascites, } \\
\text { anthrax [25] }\end{array}$ \\
\hline O. glabra Lam. DC. & $\begin{array}{l}\text { The Republic of } \\
\text { Bashkortostan 2011, The } \\
\text { Republic of Sakha (Yakutia), } \\
2000\end{array}$ & Tibetan medicine & $\begin{array}{l}\text { Saponins, alkaloids, } \\
\text { Vitamins C, P, carotene, } \\
\text { diuretic flavonoids }\end{array}$ & $\begin{array}{l}\text { Hemostatic, antipyretic, } \\
\text { anti-inflammatory, analgesic, } \\
\text { cardiovascular, depressing central } \\
\text { nervous system, with ascites and } \\
\text { edema [26] }\end{array}$ \\
\hline O. almaatensis Bajt. & Kazakhstan & Folk medicine & $\begin{array}{l}\text { Phenolcarboxylic acids, } \\
\text { flavonoids }\end{array}$ & $\begin{array}{l}\text { Coronary-expanding, } \\
\text { hypotensive [27] }\end{array}$ \\
\hline 0. deflexa (Pall.DC.) & - & Oriental medicine & $\begin{array}{l}\text { Saponins triterpene, } \\
\text { alkaloids, flavonoids }\end{array}$ & $\begin{array}{l}\text { Painkillers for intoxication and } \\
\text { septicopyemia [27] }\end{array}$ \\
\hline
\end{tabular}

O. falcate: Oxytropis falcate, O. pilosa: Oxytropis pilosa, O. myriophylla: Oxytropis myriophylla, O. lanata: Oxytropis lanata, O. muricata: Oxytropis muricata, O. oxiphylla: Oxytropis oxiphylla, O. glabra: Oxytropis glabra, O. almaatensis: Oxytropis almaatensis, O. deflexa: Oxytropis deflexa

. The parts of the plant that have traditionally been used in folk medicine are the rhizome and plant. It is traditionally used for detoxification, antiinflammation, pain relief, astringent pulse, removal of heatÿproduce muscle fibers, and cure sores. It is also used for the treatment of Malaria, hemorrhage, constipation, anthrax, topical treatment of tonsillitis, eliminating blood stasis, and remove osteoma. It controlled bleeding with astringents and improved tissue regeneration including blood vessel. $O$. falcate Bunge, called the "King of Herbs"("Chinese Materia Medica" editorial committee, 1999; Liu,1997), is the main material used to prepare a variety of Tibetan medicinal compounds and traditional Tibetan medicine, as well as more mainstream clinical medicine. In China, O. falcate Bunge, locally known as "E da Xia," was first recorded in the Chinese Pharmacopoeia as an official herbal drug in 1977 [11].

O. myriophylla (Leguminosae) is an important Mongolian medicine, widely distributed in the southeast and northwest areas of China. It has traditionally been used to treat various diseases of rubella and influenza and applied to swelling and throat pain, together with different types of bleeding. Pharmacological research on this plant showed antioxidant and anti-inflammatory properties [12].

O. ochrocephala is one of the most extensively used herbs in traditional Tibetan folk medicine to clear heat through detumescence, strengthen the body, and improve immune system [13].
0. pilosa (L.) DC is one of the Oxytropis species that are known as the "King of Herbs" in Chinese Tibetan medicine. However, some Oxytropis species contain very toxic indole alkaloids. Current knowledge about the antioxidant properties of $O$. pilosa (L.) DC is not supported by the available reference date [14]. The chemical components and methods are listed in Table 2

Currently, the pharmaceutical industries are facing many challenges and favoring the use of plant natural products over the current chemo-clinical drugs available for the treatment of different diseases. Development of resistance to commercial antimicrobial drugs due to abuse of these drugs, the reemergence of dangerous infectious diseases, high production costs, and limited effective lifespan of the synthetic therapeutic agents are important factors that have encouraged a widespread interest in drugs derived from plant extracts [20].

Some representatives of this genus, such as the Oxytropis oxiphylla and Oxytropis strobilacea, proved to be promising for the pharmaceutical industry. An extract containing biologically active flavonoid compounds, on the basis of which the preparation "Oxophil" for the treatment of rhinitis, possessing antihypoxic, analgesic, and anti-inflammatory action, and also contributing to the restoration of the affected tissues, was obtained from the aboveground part of 0 . oxiphylla [21]. 
Table 4: List of samples of O. glabra Lam. DC. collected in the Balkhash region, and collections of O. glabra Lam. DC. from the herbarium of the Institute of Botany and Phyto-Intrusion (1908-1956)

\begin{tabular}{|c|c|c|c|c|}
\hline No. & Place of collecting & Date of collecting & Collections from herbarium fund & Collectors \\
\hline 1 & $\begin{array}{l}\text { Irkutsk region, Balaganskiy district, surroundings of } \\
\text { Sherbakova village, meadow }\end{array}$ & 12.08 .1908 & & N. Maltsev \\
\hline 2 & Taldy-Kurgan Uyezd, Karatal, and Martam-Kum & 18.07.1928 & & V.I. Smirnov \\
\hline 3 & $\begin{array}{l}\text { Balkhash-Alatau, Eastern Balkhash region, lowland area, } \\
\text { the middle part of the Lepsy, and Baskan-Cul lake }\end{array}$ & 29.07.1934 & & $\begin{array}{l}\text { I.A. Limchevsky } \\
\text { O.A.Limchevsky }\end{array}$ \\
\hline 4 & $\begin{array}{l}\text { DzhungarAlatau, the foothill plain, Samarkand between } \\
\text { the rivers Baskankul and Aksu }\end{array}$ & 25.06 .1934 & & I.I. Rubtsov \\
\hline 5 & Issyk-Kola Basin $10 \mathrm{~km}$ to 103 from Rybalchy, Kyrgyz SSR & 01.08 .1938 & & A. Rubanok \\
\hline 6 & $\begin{array}{l}\text { Eastern Balkhash, Aghramant mountains height } 710 \text { in a } \\
\text { dry gorge }\end{array}$ & 24.06 .1960 & & Z.I. Polduchin \\
\hline 7 & On the sandy shore of Issyk-Kul near Rybachye & 08.07.1948 & & N.I. Rubtsov \\
\hline
\end{tabular}


Table 4: (Continued)

\begin{tabular}{|c|c|c|c|c|}
\hline No. & Place of collecting & Date of collecting & Collections from herbarium fund & Collectors \\
\hline 8 & $\begin{array}{l}\text { Western Tien Shan, the Chatkal river valley closer to } \\
\text { Yangi-Taraz village }\end{array}$ & 03.08 .1962 & & V. Palov \\
\hline 9 & $\begin{array}{l}\text { The Central Tien Shan, lake Issyk-Kul, at the Rybachye } \\
\text { shore }\end{array}$ & 23.08 .1986 & & B. Baitenov \\
\hline
\end{tabular}

O. glabra: Oxytropis glabra

When analyzing the internet resources, it was established that the widely used traditional Tibetan, Chinese, Mongolian, and Buryat medicine should include representatives of the genus Oxytropis (DC.) of the family Fabaceae (L.).

Table 3 shows that the species of the Oxytropis are widely used in Chinese, Tibetan, traditional, and oriental medicine.

A review of literary sources showed that in the countries of the near abroad popular cultivated species are: 0 . glabra Lam. DC. successfully cultivated in the CSB SB RAS (Novosibirsk); O. gmelinii Fisch. ex Boriss. - cultivated and studied in the BSI URC RAS (Ufa) since 1997, in the collection there are 4 samples; Oxytropis hippolyti Boriss. - successfully cultivated in the BCC UNSC RAS (Ufa), introduced into the Park forestry (Ufa); Oxytropis kungurensis Knjasev - successfully cultivated in the Ural Branch of the Russian Academy of Sciences (Ekaterinurg), stable, 5 samples being studied; and Oxytropis sordida Willd. Pers. - introduced into the CSI of the URC RAS (Ufa) with seeds of 2004 [28].

Of the approximately 6000 vascular plants growing in the flora of Kazakhstan, over 1500 species are characterized by medicinal properties; most of them are used in folk medicine. Such a little studied and unused in official medicine plant in Kazakhstan is a wild medicinal plant O. glabra Lam. DC [29,30].

A review in the herbarium fund of the Institute with a collection of species of 0 . glabra Lam. DC. allowed to identify the presence of at least 10 herbarium sheets.

Thus, the analysis of the herbarium fund made it possible to reveal the state and amount of the collection, the geography, the collecting time, and the collectors.

The phytochemical composition of the O. glabra Lam. DC. is not sufficiently studied. To obtain a new domestic phytopreparation, medicinal plant raw materials should cover in depth information. Under this work have been isolated two new compounds of triterpenoid saponins: $\quad 3-0-[-\beta$-D-glucopyranosyl (1-2)- $\beta$-D-glucuronopyranosyl] azukisapogenol methyl ester and 3-0-[- $\beta$-D-glucopyranosyl(1-2)- $\beta$-Dglucuronopyranosyl] azukisapogenol amide 0 . glabra Lam. DC. In the chemical composition of 0 . glabra Lam. DC., there are alkaloids, which are poisonous in the period of vegetation and feed in the flowering period. The toxic property of the alkaloid was first investigated in the work of Baisheva and Rong-man et al. [31]. Foreign scholars have come a long way to discover the ingredients of locoweed and significant effort has been devoted to their study for nearly a century. They found that the toxic ingredients of locoweed could be divided into three groups: aliphatic nitro compounds, selenium or selenium compounds and locoweed toxin. The alkaloids, which have already been isolated and identified from locoweed, can be divided into 3 groups according to their structures: Indolizidine alkaloids (swainsonine and nitrogen oxide swainsonine), quinolizidine alkaloids (anagyrine, thermopsine, lupinine and n-methylcytisine) and piperidine alkaloids. These alkaloids were also isolated from the genus Oxytropis: O. ochrocephala, O. kansuensis, Anabaena variabilis, and Anabaena strictus. Alkaloid (SW-swainsonine) is a potential inhibitor of $\alpha$-mannosidase, which can inhibit the activity of lysosomal $\alpha$-mannosidase and Golgi $\alpha$-mannosidase, leading to the accumulation of oligosaccharides and cell vacuolization. The quantitative content of an alkaloid in O. glabra Lam. DC. is presented in the work of Lu et al. and He [32]. According to foreign scientific articles, the whole work is devoted to the study of alkaloid and saponin in the field of veterinary medicine.

\section{CONCLUSION}

While analyzing the internet sources, we collected materials on the genus and species of Oxytropis which have been investigated for many years. We have studied the species of the Oxytropis and compiled a table on their chemical composition and pharmacological action. Moreover, review with the herbarium fund is provided in the form of a table.

Thus, the species Oxytropis and the substances contained in them are promising for comprehensive and in-depth study and are of scientific and practical interest as potential sources of raw materials for obtaining domestic phytopreparations.

\section{REFERENCES}

1. Suganya R, Thangaraj M. Mangrove plant derris trifoliata-evaluation of antibacterial property. Asian J Pharm Clin Res 2014;7:230-2.

2. Polozhy AV. Oxytropis. Flora of Siberia. Fabaceae. Vol. 9. Novosibirsk: Science; 1994. p. 74-151.

3. Kuvatova DN. Ecological and Biological Features of the Rare Endemic of the Southern Urals Oxytropisbaschkirensis Knjaunder Natural Conditions and Introduction. Ufa: Diss Cand Biol Sciences; 2011. p. 242

4. Kholina AB. Variability and Structure of the Populations of Oxytropis chankaensis Jurtz. Vladivostok: Diss Cand Biol Sciences; 2005. p. 199.

5. Erkul SK, Aytac Z. The revision of the genus Oxytropis (Leguminosae) in Turkey. Turk J Bot 2013;34:24-38.

6. Kholina AB, Nakonechnaya OV, Yakubov VV, Koren OG. Genetic variation in six species of the genus Oxytropis DC. (Fabaceae) from Kamchatka Peninsula. Rus J Genet 2013;49:1021-9.

7. Malyshev LI. Biodiversity of the genus Oxytropis in Asian Russia. 
Turczaninowia 2008;11:5-141.

8. Yu SI, Zibzeev EG. Ontogenetic structure and vitality of the cenopopulations of Oxytropis sulphurea (Fisch.ex) in different ecocenotic conditions of Rudny Altai and the Saurridge. Contemp Probl Ecol 2016;9:355-65.

9. Galkin AV. Protected and Economically Valuable Oxytropis DC, Species of Altai Mountains. Problems of Botany of Southern Siberia and Mongolia - XIII International Scientific and Practical Conference; 2010;4:53-4

10. Sasikala RP, Sangeetha K, Meena KS. Comparative antibacterial and antifungal activities of benzene extract of three medicinal plants. Innov J Life Sci 2017;5:1-5.

11. Zhang D, Jiang R, Hong E, Tan G, Lu D, Li Y, et al. The pharmacologically active components of Oxytropis falcate Bunge reduce ischemic-reperfusion injury in the rat heart. Legume Res 2017;40:264-70

12. She G, Wang S, Liu B. Dihydrochalcone glycosides from Oxytropis myriophylla. Chem Cent J 2011;5:71.

13. Zhang D, Lei J, Hong E, Lu D, Yuan W, Yang Z, et al. Anti-hypoxia effects of the ethanol extract of Oxytropis ochrocephala. Legume Res 2016;39:914-20.

14. Miladinović D, Miladinović L, Najman S. A study of the antioxidants in Oxytropis pilosa (L.) DC. J Serb Chem Soc 2011;76:505-12.

15. Jiang H, Hu R, Liu L. The research progress of oxytropis falcate. Chin Trad Herb Drugs 2006;27:314-5.

16. Guang-Ming Y, Ru Y, Zhao-Xian W, Fang-Fang Z, Yang P, BaoChang C. Antitumor effects of two extracts from Oxytropis falcate ohepatocellular carcinoma in vitro and in vivo. Chin J Natl Med 2013;11:519-24.

17. Cao GR, Li SJ, Duan DX, Zhao XW. Analysis of toxic component in oxytropis ochrocephala. Vet Sci China 1988;3:41-3.
18. Jiang-hai LU, Yi LI, Zhao Y, Guang-zhong TU. New flavonoids from Oxytropis myriophylla. Chem Pharm Bull 2004;52:276-8.

19. She G, Sun F, Liu B. Three new flavonoid glycosides from Oxytropis myriophylla. J Nat Med 2012;66:208-12.

20. Paramesha M, Triveni TG, Ramesh CK, Nataraj S. Bioprospecting of muntingiacalabura: Bioactive compounds and its antioxidant, antimicrobial and anthelmenthic activity. Innov J Sci 2017;5:7-11.

21. Abdulina SA. List of Vascular Plants of Kazakhstan. Almaty: Ministry of Science, Academy of Sciences of the Republic of Kazakhstan, Institute of Botany and Phytointroduction; 1999. p. 187.

22. Sakanyan EA. Pharmacognostic Study of Some Plants of the Genus Oxytropis DC. Used in Tibetan Medicine. Author's Abstract. Cand. Diss.; 1988. p. 21

23. Available from: http://www.lifebio.wiki.

24. Available from: http://www.lektrava.ru.

25. Available from: http://www.medgrasses.ru/ostrol.html.

26. Available from: https://www.znaniemed.ru/.

27. Available from: https://www.kiberis.ru/.

28. Available from: http://www.cnshb.ru/AKDiL/.

29. Konopleva EV. Comparative Characteristics of the Antihypoxic and Analgesic Activity of Some Species of Oxytropis. Petersburg: Author's Abstract of Diss. Cand. Med. Sc.; 1994. p. 24

30. Gemedzhieva NG, Ermozanova MK, Arysbaeva RB. Identification of the specific features of the distribution of Cistanche salsa in the southern Balkhash. Chem Plant Raw Mater 2016;4:123-30.

31. $\mathrm{Lu} \mathrm{H}$, Wang SS. Isolation and identification of swainsoninafrom Oxytropis glabra Lam. DC. and pathological to sd rats. Asian J Anim Vet Adv 2012;7:822-31.33.

32. He W. In vitro propagation of a poisonous plant Oxytropis glabra Lam. DC. Plant Cell Tiss Organ Cult 2015;120:49-55. 